\title{
Искусственные рэлеевские волокна и их применение в лазерах
}

\author{
С.М. Попов $^{1, *}$, О.В. Бутов ${ }^{2}$, А.П. Базакуца ${ }^{2}$, \\ М.Ю. Вяткин ${ }^{1}$, А.А. Фотиади ${ }^{3,4}$, Ю.К. Чаморовский ${ }^{1}$ \\ ${ }^{1}$ Фрязинский филиал института Радиотехники и Электроники им. В.А. Котельникова РАН \\ г. Фрязино, Россия \\ ${ }^{2}$ Институт Радиотехники и Электроники им. В.А. Котельникова РАН г. Москва, Россия \\ ${ }^{3}$ Ульяновский Государственный университет, г. Ульяновск, Россия \\ ${ }^{4}$ University of Mons г. Монс, Бельгия \\ *E-mail: sergei@popov.eu.org
}

DOI: 10.31868/RFL2020.49-50

На данный момент оптические волокна (OB) находят своё применение в различных отраслях науки и техники. Помимо уже ставшего обыденным использование $\mathrm{OB}$ в информационных системах (линии связи и волоконные датчики), так же развивается использование OB в лазерных системах. Обычно для получения лазерной генерации используются ОВ, легированные такими ионами редкоземельных элементов, как эрбий, иттербий, висмут, тулий и пр. Последнее время активно развивается новое направление - т.н. случайные волоконные лазеры [1-3]. Данное направление фотоники стало предметом большого интереса для исследователей во всем мире в связи с тем, что случайные волоконные лазеры способны генерировать свет с уникальными эксплуатационными характеристиками, не предъявляя жестких требований к оптическому резонатору. При этом усиление достигается за счёт эффектов рассеяния Рамана [2] или рассеяния Мандельштама-Бриллюэна [3]. Обратная связь в ОВ достигается за счёт слабых стационарных («вмороженных в сетку стекла») центров рассеяния, равномерно распределенных по длине волокна (Рэлеевское рассеяние). Это приводит к тому, что резонаторы случайных лазеров строятся с использованием длинных (1-100 км) ОВ. Современные тенденции случайных волоконных лазеров связаны с переходом к лазерам с резонатором [4] на основе коротких искусственных рэлеевских оптических волокон (OB, содержащих массив волоконных брэгговских решёток - ВБР) [5].

Нами разработано ОВ с ВБР, запись которых производится во время процесса вытяжки ОВ [5]. Формирование массива ВБР в таком ОВ выполняется с помощью импульсного излучения эксимерного УФ-лазера, проходящего через фазовую маску. Количество ВБР на 100 метрах такого ОВ может достигать 10000 штук. Увеличение обратного сигнала по сравнению с уровнем рассеяния Рэлея достигает 50 дБ на $\lambda=1550$ нм. Типичная ширина спектра отражения массива ВБР составляет величину 0.3 нм. При использовании чирпированной фазовой маски ширина спектра отражения массива достигает величины 4 нм. Расширение спектра отражения до 4 нм также возможно за счёт тейперирования ОВ с массивом ВБР. Запись массива ВБР возможна как в ОВ, вытягиваемых из фоточувствительной заготовки, так и в обычном одномодовом телекоммуникационном OB типа SMF-28. В последнем случае контраст записи достигает величины 25 дБ на $\lambda=1550$ нм, что значительно превышает уровень рассеяния Рэлея и расширяет возможности применения такого ОВ в системах когерентной рефлектометрии [6-7].

Используя ОВ с массивом ВБР длиной 100 метров, мы получили узкополосную лазерную генерацию с шириной линии генерации менее 10 кГц на длине волны 1552 нм [8]. Дополнительно в резонатор случайного лазера был 
добавлен короткий отрезок ( 1 м) ОВ, легированного ионами эрбия, который использовался как динамический модовый фильтр [9]. Для получения перестраиваемой лазерной генерации в полосе до 4 нм в качестве резонатора может использоваться тейперное ОВ с массивом ВБР [10].

Запись массивов ВБР также возможно производить во время вытяжки ОВ легированного ионами эрбия [11-12]. Это позволяет создать ОВ, совмещающие в себе как повышенную отражательную способность, так и возможность формирования динамических решёток, которые крайне важны для спектральной селекции лазерного излучения. На рис. 1(а) показана частотная рефлектограмма $\mathrm{OB}$, легированного ионами эрбия. Контраст записи достигает 30 дБ на длине волны 1547.6 нм с шириной спектра отражения до 0.3 нм. Радиочастотный спектр лазерной генерации, измеренный методом автогетеродинирования, показан на рис. 1(б). Эффективность лазерной генерации достигает величины $2.5 \%$ при мощности накачки 300 мВт на длине волны 976 нм. Длина резонатора - 5 м.
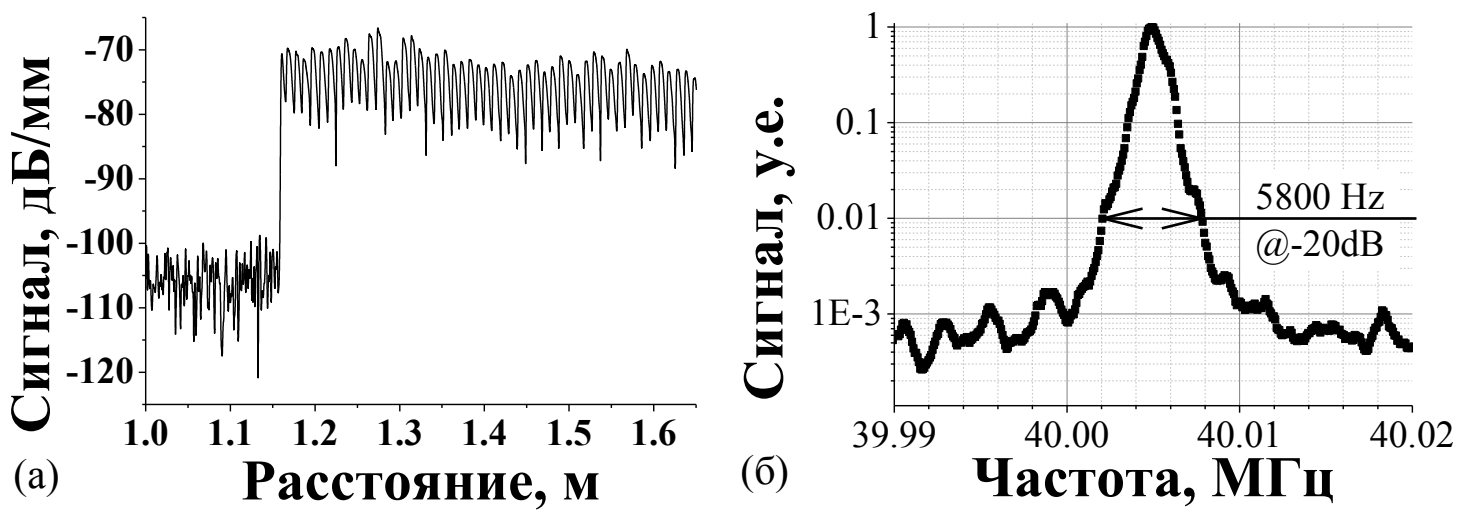

Рис. 1. Частотная рефлектограмма (а) ОВ с массивом ВБР, легированного ионами эрбия, и радиочастотный спектр лазерной генерации (б), измеренный автогетеродинным методом.

Конструкция лазера обеспечивает преобладание отражательной способности создаваемой динамической решёткой инверсной населенности над стационарными центрами отражения, что позволяет эффективно осуществлять нелинейную фильтрацию непосредственно в резонаторе ОВ [12]. При этом ширина лазерной линии сужается до частотного диапазона менее 1 кГц.

Авторы благодарят сотрудников ИРЭ РАН за изготовление заготовок (проф. К.М. Голант, В.А. Аксёнов) и вытяжки экспериментальных ОВ (И.Л. Воробьёв, В.В. Волошин, А. О. Колосовский). Работа выполнена в рамках государственного задания и при частичной поддержке гранта РФФИ и ГФЕН Китая 20-57-53013. Работа А.А.Ф. поддержана грантами РНФ 18-12-00457 и РФФИ 18-42-732001 р_мк.

\section{Литература}

[1] A.A. Fotiadi, R.V. Kiyan, Opt. Lett. 23, 1805-1807 (1998)

[2] S. Turitsyn, S. Babin, A. El-Taher, et al., Nature Photon 4, 231-235 (2010)

[3] A. Fotiadi, Nature Photon 4, 204-205 (2010)

[4] M.I. Skvortsov, S.R. Abdullina, et al., Quantum Electron 47, 696-700 (2017)

[5] I.A. Zaitsev, O.V. Butov, et al., Journal of Comm. Tech and Electr. 61, 639-645 (2016)

[6] S.M. Popov, O.V. Butov, et al.,, Quantum Electron 49, 1127-1131 (2019)

[7] D.R. Kharasov, D.M. Bengalskii, et al.,, Quantum Electron 50, 510-513 (2020)

[8] S.M. Popov, Oleg V. Butov, et al., Results in Physics 9, 806-808. (2018)

[9] I.A. Lobach, R.V. Drobyshev, et al., Optics Letters 42, 4207-4210 (2017)

[10] S.M. Popov, O.V. Butov, et al., Results in Physics 9, 625-627 (2018)

[11] S.M. Popov, O.V. Butov, et al., Results in Physics 16, 102868 (2020)

[12] S.M. Popov, O.V. Butov, et al., Proc. SPIE 11357, 113571Q (1 April 2020) 